\title{
Erratum: Climate change and the ownership of game: A concern for fenced wildlife areas
}

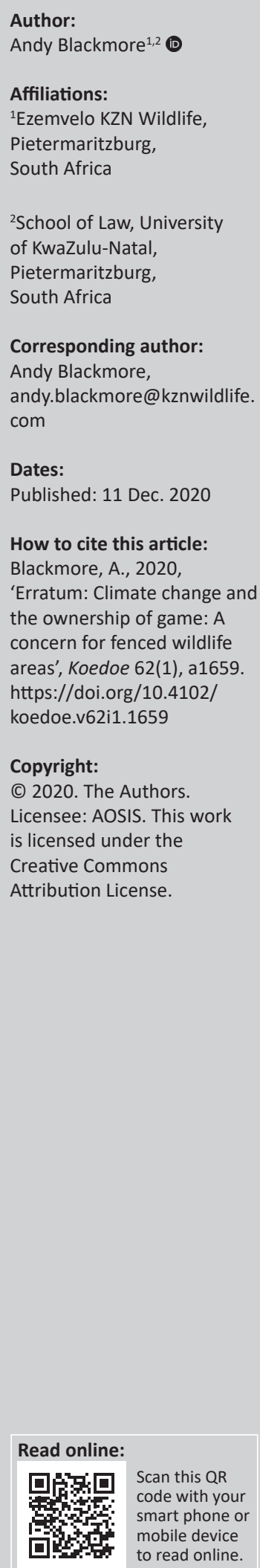

Scan this QR code with your smart phone or

In the version of this article initially published, Blackmore, A., 2020, 'Climate change and the ownership of game: A concern for fenced wildlife areas', Koedoe 62(1), a1594. https://doi. org/10.4102/koedoe.v62i1.1594, the author's second affiliation was omitted in the 'Authors' and 'Affiliations' sections. The author affiliations are now corrected as:

${ }^{1}$ Ezemvelo KZN Wildlife, Pietermaritzburg, South Africa

${ }^{2}$ School of Law, University of KwaZulu-Natal, Pietermaritzburg, South Africa

This correction does not alter the study's findings of significance or overall interpretation of the study's results. The publisher apologises for any inconvenience caused. 


\section{Climate change and the ownership of game: A concern for fenced wildlife areas}

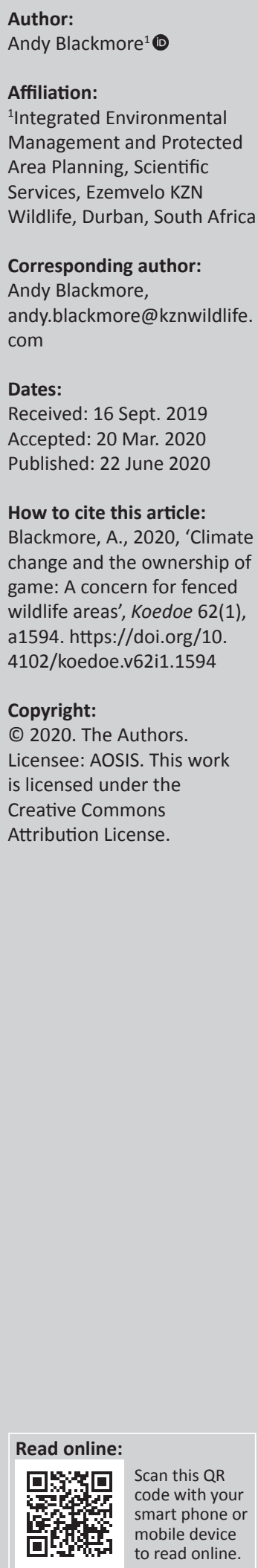

Wildlife and particularly economically valuable game are likely to be displaced as a result of the habitat change. This displacement is expressed, inter alia, in the emigration of game to a more suitable habitat. The impacts of climate change, therefore, may have significant consequences on the economic well-being of wildlife areas, which are derived from, amongst others, sale of excess animals, hunting and tourism. This article investigates whether the South African statute and common law provide sufficient protection to landowners, from a game ownership perspective, as the impacts of climate change become evident. It was discovered that the complexity derived from the relationship between landownership, legislation and common law (1) required wildlife areas to be isolated fenced areas, (2) may lead to loss of ownership of game which escapes as a consequence of climate change and (3) provided for the possible loss of ownership of all game occurring in the wildlife area and those emigrating when all or part of an encircling boundary fence is removed to establish a wildlife or climate change corridor. It is further recommended that the Game Theft Act 105 of 1991 requires substantial amendment to enable owners of wildlife areas to retain ownership of game that escapes or emigrates in response to climate change. Finally, it is recommended that landowners acquire and include into their fenced wildlife areas an additional area as an interim measure to mitigate the impacts of climate change, until such time that the desired legislative change is implemented.

Conservation implications: Climate change has serious implications for continued ownership of escaped wildlife as well as for the implementation of adaptive strategies to mitigate the impacts of a changing climate on fenced wildlife areas. The South African law needs to be revised to protect wildlife owners as the impacts of climate change become evident.

Keywords: climate change; common law; conservation; game fences; game farms; Game Theft Act 105 of 1991; game; ownership; protected areas; rural communities; wildlife.

\section{Introduction}

Climate change is increasingly being cited as one of the major challenges facing the conservation of biodiversity (Bellard et al. 2012), and with this realisation a greater emphasis is being placed on protected areas and other conserved natural areas (i.e. game farms and ranches) as refugia as well as 'island habitats' for wildlife. Although this argument may hold in open systems within which protected areas occur and where, at least, wildlife may freely move beyond the boundary of the conserved area, it may not hold for areas that are fenced, as is predominantly the case in South Africa, in a manner that limits the movement of species responding to climate change. In such circumstances, the recommendation is to physically relocate climate change-displaced species to areas of more suitable habitat, or establish biodiversity or wildlife corridors that are abundant in the scientific literature (Davidson et al. 2012; Di Minin et al. 2013; Groves et al. 2012; Hartter, Goldman \& Southworth 2011; Lister et al. 2015; Madden 2008; McDowell 2013; Minteer \& Collins 2010; Pittiglio et al. 2014; Sax, Smith \& Thompson 2009; Schwartz et al. 2012; Songhurst et al. 2016; Syombua 2013; Treves 2009; Wilke \& Rannow 2014). Although this argument is sound from many perspectives, there are a number of social, economic, conservation, legal and practical challenges that may need to be overcome before a species can be either extracted and re-introduced elsewhere, or stable and effective corridors can be established.

As the impacts of climate change manifest, conserved natural areas are likely to experience changes in rainfall (viz. water availability), temperature and vegetation type and abundance. Wildlife will most likely respond to these environmental changes by either a reduction in density or by moving out of the conserved area to seek a more suitable habitat or prey, or a combination of both (Corlett \& Westcott 2013; Davidson et al. 2012; Hannah et al. 2005; Monzón, Moyer-Horner \& Palamar 2011). Thus, from a wildlife perspective, particularly in countries that have inherited 
the Roman common law such as South Africa (Pienaar 2012; Van der Merwe \& Rabie 1974), one of the biggest challenges to be overcome before implementing the recommendation either to relocate animals or allow wildlife to move freely out and away from the conserved area is one of 'ownership'. This has received little emphasis in terms of management of conserved areas in response to climate change.

This article, from a South African perspective, therefore, focusses on the legal challenges that are likely to arise from game (a subset of wildlife) escaping from a fenced wildlife area or moving out of such area, by way of corridors, to a more suitable habitat, in response to altered habitats as a result of climate change.

\section{Discussion Ownership of game}

Ownership of game in the Roman common law, as with many legal matters, may be complex. In brief, however, game in South Africa are considered 'res nullius', meaning that they are unowned or 'property of no one' (Blackmore 2017; Muir 2016; Richter v. Du Plooy 1921; Selier et al. 2016; Van der Merwe 2002). Ownership, however, can be achieved by a person taking possession of an animal, that is, to be in purposeful physical control of it. The possession of game is commonly achieved, according to South African common law, by a person through hunting, seizing, capturing or uniquely marking (e.g. branding) an animal with a predetermined intention to take possession of it. Thus, wildlife roaming on a game farm or ranch or in a protected area (a 'wildlife area') would not necessarily be owned by the landowner. As such, a person who has hunted an animal, even without permission, could not be charged with theft (i.e. poaching), but may be liable for trespassing (Eastern Cape Parks and Tourism Agency v. Medbury (Pty) Ltd 2018; Richter v. Du Plooy 1921; Van der Merwe 2002). Irrespective of the legality of the hunt, the hunter retains legal ownership of the animal in that the hunter has purposefully taken physical control of it (Eastern Cape Parks and Tourism Agency v. Medbury (Pty) Ltd 2018; Richter v. Du Plooy 1921). Thus, for a landowner to possess and own the wildlife on his or her property, the landowner must take physical control of each animal. Once achieved, if any other person takes an animal, it would be considered theft (Magudu Game Company (Pty) Ltd $v$. Mathenjwa NO and Others 2008; Van der Merwe 2002).

As noted by Muir (2016), it is undesirable, impractical and illogical for an owner of a wildlife area to take physical control of each individual animal on the property. For this reason, the Game Theft Act 105 of 1991 was promulgated (Couzens et al. 2019; Muir 2016; Republic of South Africa 1991; Rumsey 2009; Van der Merwe 2002). This statute grants the landowner ownership of certain game on his or her property that has been adequately enclosed with a gameproof fence. Should such circumstance arise, the landowner would be reasonably entitled to retrieve the game that are known to have escaped into neighbouring properties (the 'escape rule') (Eastern Cape Parks and Tourism Agency v. Medbury (Pty) Ltd 2018; Freedman 2019). Furthermore, the landowner would not lose ownership of an animal to another person who without permission gains physical control of it (i.e. through capture or hunting) within the fenced property. Game ownership in terms of the Game Theft Act is, however, not all encompassing in that its provisions are limited to its purpose (i.e. 'to regulate the ownership of game in certain instances' - Preamble to the act) and ultimately the purpose for which the act was promulgated (to protect the interests of the commercial industry from the theft of game) (Freedman 2019; Muir 2016). It is, therefore, unlikely that the writers of the act took into consideration the common law on the natural 're-wilding' of wildlife, a principle applied to game that escape from control as a result of natural processes. Acknowledging that certainty may only be achieved in the courts, the application of this principle, within the context of climate change, may, therefore, lead to the loss in ownership of animals by the landowner. Thus, without going into detailed argument, for the purposes of this article, it is cautiously assumed that the Game Theft Act does not modify or set aside the common law principle of re-wilding.

The legal status of wildlife, therefore, as described briefly above, has significant consequences for the ownership of game and, in particular, those species that may be displaced by the impacts of climate change.

\section{Game and wildlife industry}

Since the 1990s, South Africa has witnessed an accelerated increase in the numbers and extent of wildlife ranches and private protected areas as landowners have responded to the increased demand for and the concomitant increased economic value of game. This demand was facilitated, if not created, predominantly by the security of ownership of game conferred by the Game Theft Act (Carruthers 2008; Cousins, Sadler \& Evans 2010; Eastern Cape Parks and Tourism Agency v. Medbury (Pty) Ltd 2018; Kamuti 2014; Muir 2016; Vos et al. 2019).

Following the democratisation of South Africa in 1994 and the subsequent restitution of land to communities and people dispossessed of land during the apartheid era, there has been a marked increase in the number of independent rural community protected areas and rural communities acquiring ownership of part or all of existing protected areas (Koelble 2011). In addition, a growing interest in the biodiversitytourism economy has also facilitated a number of rural communities contributing land to and expanding existing state and private protected areas (Koelble 2011). The economic value, via ownership secured by the provisions of the Game Theft Act, enables these emergent wildlife stakeholders to benefit from the wildlife economy and associated tourism industry (Koelble 2011). Two aspects that are common to private, state and communal wildlife areas are that they have well-defined boundaries and are fenced to (1) prevent the game from escaping and (2) confer statutory ownership of wild animals on the property, irrespective of whether they are naturally occurring or introduced. 
The complexity derived from the relationship between landownership (i.e. the ownership of distinct parcels of land forming constituting a ranch or wildlife management area), the Game Theft Act and the common law pertaining to game has facilitated (if not caused to) the network of wildlife areas in South Africa being isolated from each other and managed independently of neighbouring areas. The corollary of this is that wildlife areas have few functional linkages and migratory corridors for large wildlife species to, inter alia, respond to the impacts of climate change (Cushman et al. 2018; Newmark 2008).

\section{Game ownership and climate change}

The impact of climate change on enclosed wildlife areas is likely to become a significant consideration with the passage of time (Barbier et al. 2011; Hulme 2005; Mawdsley, O'Malley \& Ojima 2009; Selier et al. 2016). These impacts include, amongst others, a significant change in vegetation assemblages and the abundance of species (Carter et al. 2014; Davidson et al. 2012), displacement of habitats and species (Agrawal \& Redford 2009; Batllori et al. 2017; Carter et al. 2014; Monzón et al. 2011) and an increased risk of humanwildlife conflict as potential damage-causing animals emigrate from wildlife areas into neighbouring areas as a consequence of reduction in either the quantity of quality habitat or prey species, or both (Johnson, Karanth \& Weinthal 2018; Lamichhane et al. 2018; Nyhus 2016; Selier et al. 2016).

Although the impacts of climate change may be mitigated and ameliorated through adaptive management of the wildlife area (e.g. changes in burning regimes and addition of fodder), a threshold exists beyond which the costs and practicality of such actions outweigh the benefits gained (Koprowski \& Krausman 2019). At this point, be it a limit of acceptable change or a cautious or risk-averse threshold of potential concern (Blackmore 2015), a decision needs to be taken to either allow, inter alia, local populations to substantially reduce in numbers and condition, go extinct or to actively facilitate emigration of affected wildlife to a more suitable habitat. Notwithstanding these consequences that climate change will have on the integrity and tourism attractiveness of wildlife areas, it has serious implications for game ownership. These implications are discussed below.

\section{Common law re-wilding}

Notwithstanding the principal purpose of the Game Theft Act to provide certainty of ownership of game that have been adequately enclosed, this certainty may not be absolute or perpetual (Muir 2016). For instance, the act may not necessarily modify or override the common law principle of re-wilding.

Such circumstances occur when one or more animals escape from the wildlife area as a result of natural processes, that is, when the ecological carrying capacity is exceeded. South African common law views these animals as reverting to their wild [ferae naturae] non-captive state. Such escaped animals would be considered 'res nullius' and, as such, can be legally seized (i.e. hunted or captured) and hence owned by another person (Freedman 2019; Guyon 2018; Magudu Game Company (Pty) Ltd v. Matheniwa NO and Others 2008). It is therefore conceivable that wildlife, particularly those species that are considered 'game' in terms of the Game Theft Act, that are being displaced by the impacts of climate change, and escape from the adequately enclosed wildlife area into adjacent areas, are likely to be considered to be 're-wilding themselves' or regaining their natural freedom (Eastern Cape Parks and Tourism Agency v. Medbury (Pty) Ltd 2018; Freedman 2019). The potential consequence of climate change in this regard, together with a laissez-faire approach to this cause of displacement of wildlife, therefore, may lead to a potential loss of valuable animals (without compensation) from the wildlife area.

Although the concept of re-wilding has not been prominent in legal arguments pertaining to game ownership disputes, its consideration in the Medbury case (and others) confirms, unless successfully challenged, the existence of this principle in South African common law. It is therefore surmised that rewilding is likely to become a key basis for legal argument challenging the applicability of the escape rule, as the impacts of climate change become evident at a wildlife area level. With the progression of time, a continual reliance on the escape clause (as provided by the Game Theft Act) may, therefore, be an ill-advised strategy to be followed by game owners in that they risk losing ownership of game that escape from their fenced wildlife areas. It is thus recommended that wildlife areas should be progressively expanded, at least, as an interim measure to decrease the risk of climate change-induced escape of game and to counter arguments of re-wilding should they arise.

\section{Climate change corridors}

Establishing wildlife corridors that enable wildlife to emigrate to a more suitable habitat has been advocated as a viable adaption strategy to mitigate the impacts of climate change (Caro et al. 2009; Landguth et al. 2012; Lister et al. 2015; Mawdsley et al. 2009; Nuñez et al. 2013; Olson et al. 2009). In order for this strategy to be implemented for fenced wildlife areas, one or more corridors may need to be established through predominantly rural communities that are likely to have either a limited history of co-existence with wildlife or one of conflicts caused by damage-causing animals (Guerbois, Chapanda \& Fritz 2012; Pinter-Wollman 2012). Notwithstanding the social and economic challenges that need to be overcome to establish and maintain such corridors, several legal considerations predominate in this. Of these, the risk associated with the loss in ownership of wildlife is paramount.

In order for a fenced wildlife area to be incorporated into a corridor network, from a game perspective, the fence separating the wildlife area and the corridor would need to be removed. For South African wildlife areas, such action would result in its 'sufficiently enclosed' status falling away in terms of the Game Theft Act. As such, the landowner would immediately lose ownership of the game in that the legal status of the game would have, on removing the interleading fence between the wildlife area and an unfenced corridor, revert to its res nullius status. The removal of all or part of a 
restraining fence to enable game and other wildlife to migrate in response to the impacts of climate change therefore stands as a significant threat to, at least, the economic integrity and tourism attractiveness of any wildlife area.

\section{Conclusion}

Facilitating the movement of wildlife to a more suitable habitat via corridors has been advocated in the literature as one of the key long-term management measures that can be considered to mitigate the impacts of climate change on wildlife. Although this option is plausible from a conservation and academic perspective, it may have significant negative implications from a continued ownership of, and with that the legal protection afforded to, wildlife within fenced South African wildlife areas (e.g. game reserves, game ranches and private and communal protected areas). This article highlights the potential legal constraints facing landowners who intend to apply this mitigation measure.

The Game Theft Act 105 of 1991 overrides the res nullius common law status of game by conferring ownership on the landowner if the game in question have been adequately enclosed by a game fence. Thus, in order for the wildlife areas mentioned above (i.e. those areas that have been fenced in a manner that fulfils the requirements of the Game Theft Act) to enable game to move to a more suitable habitat, boundary fences would need to be removed or altered in a manner that would be permeable to affected wildlife. Should the climate change corridor not be fenced in compliance with the act, the legal status of the game (those within the wildlife area and corridor) will instantly revert to its common law res nullius status, that is, owned by no one and available to be claimed by any person through purposefully taking physical possession of them.

It is thus concluded that the Game Theft Act should be adjusted by an amendment legislation, to keep pace with the challenges facing acquisition and loss of ownership of wildlife in a changing environment caused by climate change. A similar conclusion is advocated by Freedman (2019) in his observation that the Game Theft Act may not necessarily provide equivalent protection to state-protected areas as that afforded to private and communal wildlife areas. Furthermore, as an interim measure, and until legislative amendments are implemented, the impacts of climate change may be decreased by a variety of management interventions, for example, a progressive expansion of the wildlife area as a means to include a suitable habitat. This action is likely to lessen the pressures inflicted by game that have been displaced by climate change on the area's fenced boundaries. It would also strengthen legal arguments against the application of the common law principle of re-wilding to and the resultant res nullius status of game that have escaped from the wildlife area. This may require redefining the 'ownership' in a manner that allows for continued ownership of wildlife that may be displaced by the impacts of climate change, and an unambiguous separation of continued ownership of an 'escaped animal' and the loss of ownership through natural re-wilding.
It is finally concluded that the practicality of recommendations eliminating out of biodiversity, and in particular wildlife research, cannot be assured without consideration of the legal context of the recommendations.

\section{Acknowledgements}

The supportive environment of Ezemvelo KZN Wildlife is correct in as this is the wording of the registered trade name. Wildlife and the University of KwaZulu-Natal are acknowledged. Magda Goosen of Ezemvelo KZN Wildlife is thanked for her comments on an earlier draft of this article.

\section{Competing interests}

The author declares no conflict of interests with regard to the writing of this article.

\section{Author contributions}

The author conceptualised the study, performed the principal analysis and wrote the manuscript.

\section{Ethical consideration}

This article followed all ethical standards for a research without direct contact with human or animal subjects.

\section{Funding information}

This research received no specific grant from any funding agency in the public, commercial or not-for-profit sector.

\section{Data availability statement}

Data sharing is not applicable to this article as no new data were created or analysed in this study.

\section{Disclaimer}

The views and opinions expressed in this article are those of the author and do not necessarily reflect the official policy or position of any affiliated agency of the author.

\section{References}

Agrawal, A. \& Redford, K., 2009, 'Conservation and displacement: An overview', Conservation and Society 7(1), 1-10.

Barbier, E.B., Hacker, S.D., Kennedy, C., Koch, E.W., Stier, A.C. \& Silliman, B.R., 2011, 'The value of estuarine and coastal ecosystem services', Ecological Monographs 81(2), 169-193. https://doi.org/10.1890/10-1510.1

Batllori, E., Parisien, M.-A., Parks, S.A., Moritz, M.A. \& Miller, C., 2017, 'Potential relocation of climatic environments suggests high rates of climate displacement within the North American protection network', Global Change Biology 23(8), 3219-3230. https://doi.org/10.1111/gcb.13663

Bellard, C., Bertelsmeier, C., Leadley, P., Thuiller, W. \& Courchamp, F., 2012, 'Impacts of climate change on the future of biodiversity', Ecology Letters 15(4), 365-377. https://doi.org/10.1111/j.1461-0248.2011.01736.x

Blackmore, A., 2015, 'The relationship between the NEMA and the public trust doctrine: The importance of the NEMA principles in safeguarding South Africa's biodiversity', South African Journal of Environmental Law and Policy 20(2), 89-118.

Blackmore, A.C., 2017, 'Public trust doctrine, research and responsible wildlife management in South Africa', Bothalia 47(1), 1-9. https://doi.org/10.4102/abc. v47i1.2217 
Caro, T., Jones, T. \& Davenport, T.R.B., 2009, 'Realities of documenting wildlife corridors in tropical countries', Biological Conservation 142(11), 2807-2811. corridors in tropical countries', Biological Cons
https://doi.org/10.1016/j.biocon.2009.06.011

Carruthers, J., 2008, 'Wilding the farm or farming the wild? The evolution of scientific game ranching in South Africa from the 1960s to the present', Transactions of the Royal Society of South Africa 63(2), 160-181. https://doi.org/10.1080/0035 9190809519220

Carter, R.W., Walsh, S.J., Jacobson, C. \& Miller, M.L., 2014, 'In the george wright forum', George Wright Society 31(3), 245-255.

Corlett, R.T. \& Westcott, D.A., 2013, 'Will plant movements keep up with climate change?', Trends in Ecology \& Evolution 28(8), 482-488. https://doi.org/10.1016/j. tree.2013.04.003

Couzens, E., 2019, International encyclopaedia of law: Environmental law - South Africa, 2 nd edn., p. 600, Kluwer Law International, The Netherlands, ISBN 9789065449450.

Couzens, E. International Encyclopaedia of Law: Environmental Law - South Africa (2nd ed, 2019) Kluwer Law International, The Netherlands. 600p ISBN: 978906 5449450

Cushman, S.A., Elliot, N.B., Bauer, D., Kesch, K., Bahaa-el-din, L., Bothwell, H. et al., 2018, 'Prioritizing core areas, corridors and conflict hotspots for lion conservation in southern Africa', PLoS One 13(7), e0196213. https://doi.org/10.1371/journal. pone.0196213

Davidson, A.D., Boyer, A.G., Kim, H., Pompa-Mansilla, S., Hamilton, M.J., Costa, D.P. et al., 2012, 'Drivers and hotspots of extinction risk in marine mammals', Proceedings of the National Academy of Sciences 109(9), 3395-3400. https://doi. Proceedings of the National Acade
org/10.1073/pnas.1121469109

Di Minin, E., Hunter, L.T.B., Balme, G.A., Smith, R.J., Goodman, P.S. \& Slotow, R., 2013, 'Creating larger and better connected protected areas enhances the persistence of big game species in the Maputaland-Pondoland-Albany Biodiversity hotspot', PLoS One 8(8), e71788. https://doi.org/10.1371/journal.pone.0071788

Eastern Cape Parks and Tourism Agency v Medbury (Pty) Ltd, (2018), 206, ZASCA34.

Freedman, W., 2019, 'A critical analysis of the escape rule - Eastern Cape Parks and Tourism Agency v Medbury (Pty) Ltd t/a Crown River Safari 20184 SA 206 (SCA)', Journal of South African Law 2019(2), 374-382.

Groves, C.R., Game, E.T., Anderson, M.G., Cross, M., Enquist, C., Ferdaña, Z. et al. (2012). 'Incorporating climate change into systematic conservation planning', Biodiversity and Conservation 21, 1651-1671. https://doi.org/10.1007/s10531 012-0269-3

Guerbois, C., Chapanda, E. \& Fritz, H., 2012, ‘Combining multi-scale socio-ecological approaches to understand the susceptibility of subsistence farmers to elephant crop raiding on the edge of a protected area', Journal of Applied Ecology 49(5), 1149-1158. https://doi.org/10.1111/j.1365-2664.2012.02192.x

Guyon, F., 2018, 'Le massif des Vosges face à un cas de "ré-ensauvagement" par le cerf: Analyse de l'influence des facteurs sociaux (professionnels et culturels) sur les représentations et qualifications attribuées au cerf, à la forêt et aux activités
des hommes', VertigO-la revue électronique en sciences de l'environnement 18(3), des hommes', VertigO-la revue électronique en

Hannah, L., Midgley, G., Hughes, G. \& Bomhard, B., 2005, 'The view from the Cape: Extinction risk, protected areas, and climate change', BioScience 55(3), 231-242. Extinction risk, protected areas, and climate change', BioScience 55(3),
https://doi.org/10.1641/0006-3568(2005)055[0231:TVFTCE]2.0.CO;2

Hartter, J., Goldman, A. \& Southworth, J., 2011, 'Responses by households to resource scarcity and human-wildlife conflict: Issues of fortress conservation and the surrounding agricultural landscape', Journal for Nature Conservation 19(2), 79-86. https://doi.org/10.1016/j.jnc.2010.06.005

Hulme, P.E., 2005, 'Adapting to climate change: Is there scope for ecological management in the face of a global threat?', Journal of Applied Ecology 42(5), 784-794. https://doi.org/10.1111/j.1365-2664.2005.01082.x

Johnson, M.F., Karanth, K.K. \& Weinthal, E., 2018, 'Compensation as a policy for mitigating human-wildlife conflict around four protected areas in Rajasthan, India', Conservation and Society 16(3), 305-319. https://doi.org/10.4103/cs. Cs_17_1

Kamuti, T., 2014, 'The fractured state in the governance of private game farming: The case of KwaZulu-Natal Province, South Africa', Journal of Contemporary African Studies 32(2), 190-206. https://doi.org/10.1080/02589001.2014.936678

Koelble, T.A., 2011, 'Ecology, economy and empowerment: Eco-tourism and the game lodge industry in South Africa', Business and Politics 13(1), 1-24. https://doi. org/10.2202/1469-3569.1333

Koprowski, J.L. \& Krausman, P.R., 2019, International wildlife management: Conservation challenges in a changing world, JHU Press, Baltimore.

Lamichhane, B.R., Persoon, G.A., Leirs, H., Poudel, S., Subedi, N., Pokheral, C.P. et al., 2018, 'Spatio-temporal patterns of attacks on human and economic losses from wildlife in Chitwan National Park, Nepal', PLoS One 13(4), e0195373. https://doi. org/10.1371/journal.pone.0195373

Landguth, E.L., Hand, B.K., Glassy, J., Cushman, S.A. \& Sawaya, M.A., 2012, 'UNICOR: A species connectivity and corridor network simulator', Ecography 35(1), 9-14. https://doi.org/10.1111/j.1600-0587.2011.07149.x

Lister, N.-M., Brocki, M. \& Ament, R., 2015, 'Integrated adaptive design for wildlife movement under climate change', Frontiers in Ecology and the Environment 13(9), 493-502. https://doi.org/10.1890/150080
Madden, F.M., 2008, 'The growing conflict between humans and wildlife: Law and policy as contributing and mitigating factors', Journal of International Wildlife Law \& Policy 11(2-3), 189-206. https://doi.org/10.1080/13880290802470281

Magudu Game Company (Pty) Ltd v Mathenjwa N.O. (2008) 2 All SA 338 (N)

Mawdsley, J.R., O'Malley, R. \& Ojima, D.S., 2009, 'A review of climate-change adaptation strategies for wildlife management and biodiversity conservation', Conservation Biology 23(5), 1080-1089. https://doi.org/10.1111/j.1523-1739. 2009.01264.x

McDowell, C., 2013, 'Climate-change adaptation and mitigation: Implications for land acquisition and population relocation', Development Policy Review 31(6), 677-695. https://doi.org/10.1111/dpr.12030

Minteer, B.A. \& Collins, J.P., 2010, 'Move it or lose it? The ecological ethics of relocating species under climate change', Ecological Applications 20(7), 1801-1804. https:// doi.org/10.1890/10-0318.1

Monzón, J., Moyer-Horner, L. \& Palamar, M.B., 2011, 'Climate change and species range dynamics in protected areas', BioScience 61(10), 752-761. https://doi. org/10.1525/bio.2011.61.10.5

Muir, A., 2016, 'Offences, game and property - Some unresolved issues surrounding ownership of wild animals in South Africa', Stellenbosch Law Review 27(1), 136-160.

Newmark, W.D., 2008, 'Isolation of African protected areas', Frontiers in Ecology and the Environment 6(6), 321-328. https://doi.org/10.1890/070003

Nuñez, T.A., Lawler, J.J., Mcrae, B.H., Pierce, D.J., Krosby, M.B., Kavanagh, D.M. et al., 2013, 'Connectivity planning to address climate change: Climate change and connectivity', Conservation Biology 27(2), 407-416. https://doi.org/10.1111/cobi.12014

Nyhus, P.J., 2016, 'Human-wildlife conflict and coexistence', Annual Review of Environment and Resources 41, 143-171. https://doi.org/10.1146/annurevenviron-110615-085634

Olson, D., O'Connell, M., Fang, Y.-C., Burger, J. \& Rayburn, R., 2009, 'Managing for climate change within protected area landscapes', Natural Areas Journal 29(4), 394-399. https://doi.org/10.3375/043.029.0406

Pienaar, G., 2012, 'The methodology used to interpret customary land tenure', Potchefstroom Electronic Law Journal 15(3), 153-183. https://doi.org/10.4314/ pelj.v15i3.7

Pinter-Wollman, N., 2012, 'Human-elephant conflict in Africa: The legal and political viability of translocations, wildlife corridors, and Transfrontier parks for large mammal conservation', Journal of International Wildlife Law \& Policy 15(2), 152-166. https://doi.org/10.1080/13880292.2012.678793

Pittiglio, C., Skidmore, A.K., Van Gils, H.A.M.J., McCall, M.K. \& Prins, H.H.T., 2014 'Smallholder farms as stepping stone corridors for crop-raiding elephant in Northern Tanzania: Integration of Bayesian expert system and network simulator', AMBIO 43, 149-161. https://doi.org/10.1007/s13280-013-0437-z Richter v Du Plooy (1921), OPT 117.

Rumsey, A.B., 2009, Terrestrial wild animals, 2nd edn., H. Strydom \& N. King (eds.), Juta, Cape Town.

Sax, D.F., Smith, K.F. \& Thompson, A.R., 2009, 'Managed relocation: A nuanced evaluation is needed', Trends in Ecology \& Evolution 24, 472-473. https://doi. org/10.1016/j.tree.2009.05.004

Schwartz, M.W., Hellmann, J.J., McLachlan, J.M., Sax, D.F., Borevitz, J.O., Brennan, J. et al., 2012, 'Managed relocation: Integrating the scientific, regulatory, and ethical challenges', BioScience 62(8), 732-743. https://doi.org/10.1525/ bio.2012.62.8.6

Selier, S.J., Slotow, R., Blackmore, A. \& Trouwborst, A., 2016, 'The legal challenges of transboundary wildlife management at the population level: The case of a trilateral elephant population in southern Africa', Journal of International Wildlife Law \& Policy 19(2), 101-135. https://doi.org/10.1080/13880292.2016.1167460

Songhurst, A., McCulloch, G. \& Coulson, T., 2016, 'Finding pathways to humanelephant coexistence: A risky business', Oryx 50(4), 713-720. https://doi. org/10.1017/S0030605315000344

Syombua, J., 2013, 'Land use and land cover changes and their implications for human-wildlife conflicts in the semi-arid rangelands of southern Kenya', Journal of Geography and Regional Planning 6(5), 193-199. https://doi.org/10.5897/ JGRP2013.0365

Treves, A., 2009, 'The human dimensions of conflicts with wildlife around protected areas', in M.J. Manfredo, J.J. Vaske, P. Brown, D.J. Decker \& E.A. Duke (eds.), Wildlife and society: The science of human dimensions, pp. 214-228, Island Press, Washington, DC

Van der Merwe, C.G., 2002, 'Things', in W.A. Joubert (ed.), The Law of South Africa (Lawsa), Butterworths, Durban.

Van der Merwe, C.G. \& Rabie, M.A., 1974, 'Eiendom van Wildre Diere', Tydskrif vir Hedendaagse Romeins-Hollandse Reg 37, pp. 38-48.

Vos, A., Clements, H.S., Biggs, D. \& Cumming, G.S., 2019, 'The dynamics of proclaimed privately protected areas in South Africa over 83 years', Conservation Letters 12(6), e12644. https://doi.org/10.1111/conl.12644

Wilke, C. \& Rannow, S., 2014, 'A methodical framework for climate change-adapted management in protected areas', in S. Rannow \& M. Neubert (eds.), Managing protected areas in central and eastern Europe under climate change, pp. 159-172, Springer Netherlands, Dordrecht. 